\title{
Exudation of Allelopathic Compound from Plant Roots of Sweet Vernalgrass (Anthoxanthum odoratum)*
}

\author{
Yoshito Yamamoto** and Yoshiharu Fujii***
}

KeyWords: Anthoxanthum odoratum, allelochemicals, root, exudation, coumarin. キーワード: ハルガヤ, アレロパシー物質, 根,
渗出, クマリン

\section{Introduction}

Several studies have been conducted on the allelopathy of sweet vernalgrass (Anthoxanthum odoratum $)^{10,11)}$, and Yamamoto ${ }^{17)}$ isolated and identified coumarin as an allelopathic compound produced by $A$. odoratum. It has been reported that coumarin is present in all parts of this plant, and is particularly highly concentrated in the leaves, accounting for more than $2.5 \%$ of dry leaf weight in June ${ }^{17)}$. Yamamoto ${ }^{18)}$ indicated that coumarin of the $A$. odoratum plant residue easily moves into the soil after rainfall where both soil type and the presence of microorganisms are related to its disappearance.

Evidence also indicated that allelopathic compounds come from plants by volatiliza-

* This study was supported in part by a Grant-inAid (Bio Cosmos Program) from the Ministry of Agriculture, Forestry, and Fisheries (BCP97-II-A $-1)$.

** Department of Ecology, National Grassland Research Institute, Nishinasuno, Tochigi 329-27, Japan. Present address : Department of Grasslands, Kyushu National Agricultural Experiment Station, Nishigoushi, Kumamoto 861-11, Japan.

*** Department of Environmental Biology, National Institute of Agro-Environmental Sciences, Tsukuba, Ibaraki 305, Japan.

(Accepted September 30, 1996)

山本嘉人**・藤井義晴***：ハルガヤ (Anthoxanthum odoratum) 根からのアレロパシー物質の渗出. **草地試 験場 (現在：九州農業試験場), ${ }^{* * *}$ 農業環境技術研究所 tion, decomposition of residues, exudation from roots or by leaching during rain ${ }^{14)}$. Many kinds of plant root exudates are report$\mathrm{ed}^{15)}$, and Rice ${ }^{14)}$ indicated that evidence was quite strong that many identified allelopathic compounds and other related compounds were exuded from plant roots, taken up by neighboring plants, and cause growth changes in the receptor species. The concentration of these compounds exuded from plant roots determined to estimate their allelopathic potential ${ }^{5}$. This assessment is difficult, however, Tang and Young ${ }^{16)}$ developed an excellent technique using $\mathrm{XAD}^{-4}$ resin to collect exudates from roots of plants, and identified 16 allelochemicals in the root exudate of Hemarthria altissima. In this experiment, we applied the new "Plant Box Method" developed by Fujii and Shibuya ${ }^{6)}$ to determine the concentration of allelopathic compound exuded from the root of $A$. odor atum. The principle of this method involves assessing the effect of root exudates of the living donor plant by soaking its root in agar medium and mixed culture in the same medium in a plant box for tissue culture ${ }^{6,7)}$. Fujii $^{7)}$ tested more than 250 species with this technique and indicated that the activities of several species were prominent.

The purpose of the experiments reported here was to investigate the exudation of allelopathic compound from the roots of $A$. odoratum using this Plant Box Method, and to assure that the exuded compound has the potential to impact the plant species sur- 
rounding $A$. odoratum.

\section{Materials and Methods}

Assessment of the effect of the $A$. odoratum plant root exudates

In November an $A$. odoratum plant was collected from grassland and grown under a sand culture condition in a greenhouse for about one month. After sand had been carefully washed off the plant with water so that the roots were not damaged, the plant was placed in a $60 \mathrm{~mm}$-high $\times 32 \mathrm{~mm}$-diameter tube made of nylon insect netting which the root could not pass through. The tube was then placed in a plant box $(60 \mathrm{~mm} \times 60 \mathrm{~mm} \times$ $100 \mathrm{~mm}$-high) for tissue culture, $230 \mathrm{ml}$ of $0.5 \%$ agar aqueous solution at $45^{\circ} \mathrm{C}$ was added to the box and tube, then cooled rapidly using ice water taking care not to damage the roots. After the agar solution gelled, lettuce seeds were placed on the surface of agar medium with a space of $10 \mathrm{~mm}$ around the tube $^{6,7)}$. The $A$. odoratum and lettuce seeds in agar medium were grown in the laboratory under a daylight condition for 5 days, and the length of lettuce radicles was measured. The A. odoratum plant used in this experiment was $110 \mathrm{~mm}$-high with 20 stems, and the dry weight of root and shoot parts at the end of experiment was $189 \mathrm{mg}$ and $666 \mathrm{mg}$, respectively.

Qualitative analysis of coumarin in agar medium

Part of the agar medium close to the $A$. odoratum in the plant box was filtered using a hypodermic syringe with a membrane filter (Millipore 13-FH). Qualitative analysis of coumarin in this filtrate was carried out using a high-performance liquid chromatography (Shimadzu LC-8A). The analytical conditions were as follows : Column-Shimpac CLC-ODS(M); mobile phase-2\% acetic acid / methanol $(1: 1, \mathrm{v} / \mathrm{v}), 0.7 \mathrm{ml} / \mathrm{min}$; col- umn temperature $-25^{\circ} \mathrm{C}$; UV detector-275nm. Bioassay of lettuce in agar medium containing coumarin

The bioassay of lettuce in the agar medium containing coumarin was carried out to estimate the content of coumarin around $A$. odoratum. Twenty $\mathrm{ml}$ of $0.5 \%$ agar water solution at $45^{\circ} \mathrm{C}$ containing $0,0.3,1,3,10,30$ and $100 \mathrm{ppm}$ coumarin was put in each of 10 test tubes ( $130 \mathrm{~mm}$-high $\times 15 \mathrm{~mm}$-diameter), respectively. After this solution gelled, one lettuce seed was placed on the surface of the medium in each tube. Lettuce was grown for 5 days, and the length of the radicles was measured.

\section{Results and Discussion}

Coumarin is known to inhibit the growth or germination of many plant species ${ }^{1,4,9,13}$. Yamamoto ${ }^{17}$ ) isolated and identified coumarin as an allelopathic compound produced by A. odoratum. Evidence indicated that such compounds come from plants by volatilization, decomposition of residue, exudation from roots or leaching by rain ${ }^{14)}$. Coumarin was highly concentrated in the leaves, accounting for more than $2.5 \%$ of dry leaf weight in June ${ }^{17)}$, Yamamoto ${ }^{18)}$ indicated that coumarin of $A$. odoratum plant residue easily drains into the soil after rainfall, and that both soil type and the presence of microorganisms are related to its disappearance in the soil. Yamamoto ${ }^{18)}$ suggested, however, that it could not be determined whether the allelopathy of $A$. odoratum in Zoysia-grassland was caused by the decomposition of its plant residue, because high concentrations of coumarin in soil due to decomposition of plant residues are temporary, and other pathways of coumarin movement from $A$. odoratum were not studied. We therefore sought to determine the exudation route of coumarin from $A$. odoratum roots. 
The growth of lettuce around the $A$. odoratum plant in agar medium was inhibited. Lettuce radicle length tended to be shorter closer to the plant (Figure 1). Correlation coefficient, 0.851 , between lettuce radicle length and distance from the plant in agar medium was significant at $\mathrm{P}<0.01$. The average of lettuce radicle length in agar medium in the control box without $A$. odoratum was $46.1 \mathrm{~mm}$, and the intercept of this regression line, $20.5 \mathrm{~mm}$, close to $A$. odoratum was limited to $55.6 \%$ compared to control. Lettuce growth was inhibited by a compound exuded from $A$. odoratum. Judging from the fact that coumarin was present at $47-461 \mathrm{ppm}$ in the plant root $^{17)}$, there is a strong possibility that the inhibiting compound was coumarin.

We tried to measure the coumarin content in agar medium around $A$. odoratum, but found no coumarin. The retention time of one peak of the chromatogram of agar medium close to $A$. odoratum in the plant box was the same as that of coumarin, but its quantity was too small to measure, suggesting that this method of detecting of coumarin in agar

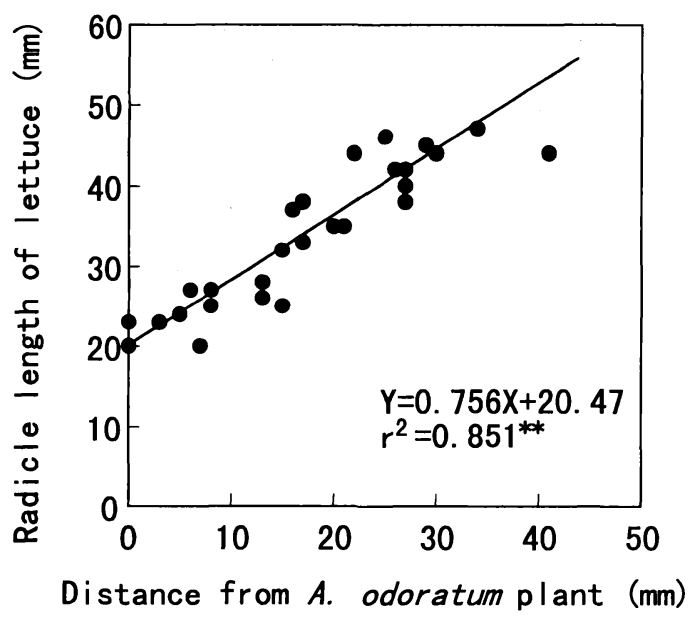

Fig. 1. Relationship between distance from Anthoxanthum odoratum plant and radicle length of lettuce in agar medium in plant box. medium was unsuitable.

Therefore, we assumed that the inhibition of lettuce radicle length was due to coumarin exuded from $A$. odoratum, and carried out bioassay using lettuce seeds in agar medium containing coumarin to estimate the content of coumarin around this plant in the medium. The growth of lettuce tended to be inhibited at a high concentration of coumarin in the medium, and lettuce seeds did not germinate at $100 \mathrm{ppm}$ coumarin concentration (Figure 2 ). The relation of coumarin concentration in agar medium and the rate of inhibition of lettuce radicle length compared with control in medium without coumarin were shown by the reverse $\mathrm{S}$ curve on the logarithmic axis for concentration ; only the range between 0.3 and $3 \mathrm{ppm}$ of coumarin concentration was estimated by the equation. It can be suggested that the inhibition rate of lettuce growth in agar medium of a flat concentation of coumarin in the glass tube was different from that of the rising concentration of coumarin in the plant box. If there were no difference in both cases, from the results that inhibition

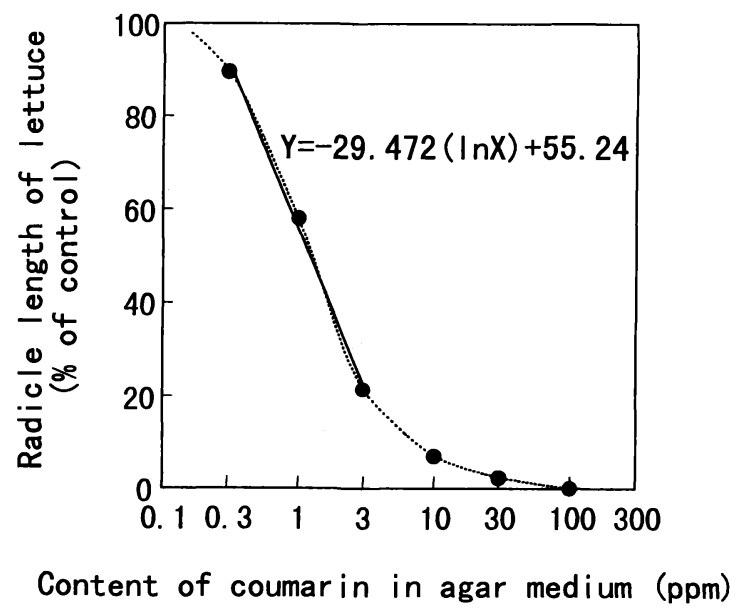

Fig. 2. Bioassay using lettuce in agar medium containing coumarin. 
rate of lettuce radicle length were estimated by the equation in range between 0.3 and 3 ppm (Figure 2) and that the lettuce radicle length at the point of close to $A$. odoratum was limited to $55.6 \%$ compared with control (Figure 1), it was suggested that the contents of coumarin at the point of close to $A$. odor. atum was $1.45 \mathrm{ppm}$. The average of lettuce radicle length in agar medium with $A$. odoratum in the plant box was about $33.2 \mathrm{~mm}$, which was $72.1 \%$ that of control. The average coumarin content in the medium around the plant in the plant box was thus estimated as $0.57 \mathrm{ppm}$ from the equation in Figure 2. As the volume of medium in the box was $230 \mathrm{ml}$, the amount of coumarin in the box was estimated to be $131 \mathrm{mg}$. It was estimated from these calculations that $131 \mathrm{mg}$ of coumarin was exuded from $A$. odoratum root over 5 days, when the dry weight of the root was 189 mg. These estimated values were limited under the condition of agar medium culture, and the amount of coumarin exuded from $A$. odoratum root were believed to vary with the growth stage and environmental conditions. Perez and Ormeno-Nune ${ }^{12)}$ reported that the amount of scopoletin in root exudates of Avena fatua increased with the time of collection.

The dynamics of coumarin in soil varied depending on soil type and microoganism activity : when a coumarin water solution was added to the soil, the recovery percentage of coumarin was about $80 \%$ in Cambisols and $40 \%$ in Andosols, and the rate in Andosols at $15^{\circ} \mathrm{C}$ had reduced by half after one week $^{18)}$. These low recovery percentages were suggested to be due to absorption by the soil and decomposition by microorganisms. One hundred thirty-one $\mathrm{mg}$ of coumarin exuded from. $A$. odoratum root was too small to compare with the amount of coumarin movement from residues of this plant. How- ever, high concentrations of coumarin in soil resulting from decomposition of plant residues are temporary, and it is emphasized here that the amount of coumarin exuded from $A$. odoratum root is continuous. Allelopathy is known to play a significant role in the dominance of grassland communities ${ }^{2,3,8,14}$. From the above results, coumarin exuded from $A$. odoratum root has the potential to affect growth and germination of plant species surrounding $A$. odoratum in grasslands.

Acknowledgments : The authors wish to express their gratitude to Dr. Y. Nada and Dr. N. Koyama for their critical reading of the manuscript and their valuable comments.

\section{References}

1) Avers, C. J. and R. H. Goodwin. 1956. Studies on roots. 5. Effects of coumarin and scopoletin on the standard root growth pattern of Phleum pratense. Amer. J. Bot. 43, 612-620.

2 ) Chou, C. H. 1987. The role of allelopathy in agroecosystem : Studies from tropical Taiwan. Ecological studies 78 Agroecology Springer-Verlag. Berlin, 104-121

3 ) Chou, C. H. and Y. F. Lee. 1991. Allelopathic dominance of Miscanthus transmorrisonensis in an alpine grassland community in Taiwan. J. Chem. Ecol. 17, 2267-2281.

4 ) Dornbos, D. L. and G. F Spencer. 1990. Natural products phytotoxicity. A bioassay suitable for small quantities of slightly water-soluble compounds. J. Chem. Ecol. 16, 339-352.

5 ) Fay, P. K., and W. B. Duke. 1977. An assessment of allelopathic potential in Aveana germ plasm. Weed Sci. 25, 224-228.

6 ) Fuji, Y. and T. Shibuya. 1991. A new bioassay for allelopathy with agar medium. II. Mixed culture of allelopathic candidates with acceptor plants in agar medium. Weed Res., Japan 36 (suppl.), 152 -153. (in Japanese)

7 ) Fujii, Y. 1994. Screening of allelopathic candidates by new specific discrimination, and assessment methods for allelopathy, and the identifica- 
tion of L-DOPA as the allelopathic substance from the most promising velvetbean (Mucuna prurieus). Bull. Nat. Inst. Agro-Environmental Sciences 10, 115-218. (in Japanese with English summary)

8 ) Heisey, R. M. and C. C. Delwiche. 1985. Allelopathic effects of Trichostema lanceolatum (LABIATAE) in the California annual grassland. J. Ecol. 73, 729-742.

9) $\mathrm{Hu}, \mathrm{Q}$. H. 1985. Effect of coumarin on some physiological processes in Boron-deficient plants. Plant Physiology Comm. 6, 25-26.

10) Newman. E. I. and M. H. Miller. 1977. Allelopath$\mathrm{y}$ among some British grassland species. 2. Influence of root exudates on phosphorus uptake. J. Ecol. 65, 399-411.

11) Newman, E. I., and A. D. Rovia. 1975. Allelopath$\mathrm{y}$ among some British grassland species. J. Ecol. 63, 727-737.

12) Perez, F. J. and J. Ormeno-Nunez. 1991. Root exudates of wild oats : Allelopathic effect on spring wheat. Phytochemistry 30, 2199-2202.

13) Putnam, A. R. 1988. Allelochemicals from Plants as Herbicies. Weed Technology 2, 510-518.

14) Rice, E. L. 1984. Allelopathy, 2nd ed. Academic Press, New York.

15) Rovira, A. D. 1969. Plant root exudates. Bot. Rev. 35, 35-57.

16) Tang, C. S. and C. C. Young. 1982. Collection and identification of allelopathic compounds from the undisturbed root system of Bigalta limpograss (Hemarthria altissima). Plant Physiol. 69, 155-160.

17) Yamamoto, Y. 1995. Allelopathic potential of Anthoxanthum odoratum for invading Zoysiagrassland in Japan. J. Chem. Ecol. 21, 1365-1373.

18) Yamamoto, Y. 1997. Movement of allelopathic compound coumarin from plant residue of Anth. oxanthum odoratum to soil. Proc. XVIII Int. Grassld Congr. (in press) 